\title{
Effects of dietary vitamin E and organic selenium supplementation on the oxidative stability of lamb meat*
}

\author{
X. Han, J.G. Li' ${ }^{1}$ Y.X. Gao, Q.F. Li and Y.F. Cao \\ Department of Animal Science and Technology, Agricultural University of HeBei \\ Baoding, 071001, P.R. China
}

\begin{abstract}
A total of 72 healthy $F_{1}$ lambs (Suffolk $\widehat{\partial} \times$ Small Tailed Han sheep $\odot$ ) were allocated to nine groups in a $3 \times 3$ factorial design to study the effects of dietary vitamin $E(V E)$ and selenium supplementation on the oxidative stability of lamb meat. Dietary VE supplementation (500 or $1000 \mathrm{IU} / \mathrm{d}$ ) increased $\alpha$-tocopherol concentrations in serum and longissimus muscle $(\mathrm{P}<0.01)$. Se supplementation $(0.2$ and $0.4 \mathrm{mg} / \mathrm{kg} \mathrm{DM}$ of concentrate) increased Se concentrations in serum and longissimus muscle $(\mathrm{P}<0.05)$, but no influence on the lipid oxidation, discolouration and water retention of muscle. VE supplementation at 500 and 1000 IU/d significantly decreased drip loss of longissimus muscle $(\mathrm{P}<0.05)$ and improved the oxidative stability of lamb meat during the whole period of storage $(\mathrm{P}<0.01)$. VE supplementation increased a* values of longissimus muscle at $\mathrm{d} 10-13$ of storage at $4^{\circ} \mathrm{C}(\mathrm{P}<0.05)$.
\end{abstract}

KEY WORDS: vitamin E, organic selenium, lamb meat, oxidative stability

\section{INTRODUCTION}

Vitamin E (VE) and selenium (Se) are important components of the antioxidant defence system of living tissues (Gerloff, 1992). These antioxidant functions are important because the oxidation of muscle lipids after slaughter can adversely affect the flavour and nutritive value of fresh, frozen, and cooked meat and meat products (Morrissey, 1998). Dietary Se supplementation did not affect significantly muscle Se levels, or susceptibility to lipid and oxymyoglobin oxidation in the presence or absence of VE. Dietary Se stimulated the biosynthesis yield of selenocysteine-proteins, e.g., the Se-dependent glutathione peroxidase (Combs, 1981).

\footnotetext{
* Supported by the National Key Technology R\&D Program of China, 2004BA514A-04 and Hebei Provincial Committee for Scientific Research Program, 06547004D-6

${ }^{1}$ Corresponding author: e-mail: jgli@hebau.edu.cn
} 
It is well established that VE supplementation of the diets of meat-producing animals effectively elevates the concentration of VE in muscles, and lowers the susceptibility of muscle and, ultimately, meat products to lipid oxidation and the onset of flavour defects (Monahan et al., 1990; Guidera et al., 1997; Lauridsen et al., 1997). The concentration of Se in muscles has been shown to respond to dietary Se supplementation in pigs (Goehring et al., 1984) or beef cattle (Ekholm et al., 1991).

The objective of the present study was to determine the effect of dietary VE and $\mathrm{Se}$ on the oxidative stability of meat, and to examine potential interactions between the effects of dietary VE and Se.

\section{MATERIAL AND METHODS}

The vitamin E supplement used in the animal feed was supplied by DSM Co. Ltd. (China) and was stated by the supplier to contain 50\% DL- $\alpha$-tocopheryl acetate. Organic Se $\left(\mathrm{Sel}-\mathrm{Plex}{ }^{\mathrm{TM}}\right)$ was obtained from Alltech China, and was stated by the manufacturer to contain about organic Se $1.000 \mathrm{mg} / \mathrm{kg}$. The experiment was carried out on Fuhua Agri Husb LD Farm with $\mathrm{F}_{1}$ lambs (Suffolk ${ }^{\lambda} \times$ Small Tailed Han sheep ) . A $3 \times 3$ factorial design was used to study the effects of dietary VE $(0,500$ and $1000 \mathrm{IU} / \mathrm{d})$ and organic Se $(0,0.2$ and $0.4 \mathrm{mg} / \mathrm{kg} \mathrm{DM})$ supplementation on the oxidative stability of lamb meat. A total of 72 healthy $F_{1}$ lambs (age: $120 \pm 10 \mathrm{~d}$, body weight: $22.0 \pm 2.4 \mathrm{~kg}$ ) were randomly allocated to one of nine groups with 8 replicates. The lambs were fed maize silage $(2 \mathrm{~kg} / \mathrm{d})$ and a base concentrate (55:45\% roughage to concentrate) with different levels of VE and Se. After 60 days of feeding, 45 lambs were slaughtered as a sub-sample to evaluate the effects. Concentrate composition is shown in Table 1.

Table 1. Ingredient composition and major nutrient contents of basic concentrate

\begin{tabular}{lclr}
\hline Ingredients, \% DM & \multicolumn{2}{c}{ Nutrient contents } \\
\hline Maize & 60 & Crude protein, \% & 17.00 \\
Soya meal & 24 & $\mathrm{DE}, \mathrm{MJ} / \mathrm{kg}$ & 13.45 \\
Wheat bran $^{13}$ & 13 & $\mathrm{Ca}, \%$ & 1.24 \\
Premix $^{1}$ & 3 & $\mathrm{P}, \%$ & 0.57 \\
& & $\alpha$-tocopherol, $\mathrm{mg} / \mathrm{kg}$ & 18.65 \\
& & $\mathrm{Se}, \mathrm{mg} / \mathrm{kg}$ & 0.09 \\
\hline
\end{tabular}

${ }^{1}$ Premix provided the following per kg of diet, IU: vit. A 1.900; vit. D 190; g: $\mathrm{NaCl} 4.4$; mg: Mn 14; Fe 8.5; Cu 2.3; I 23; Co 24

\section{Samplings, recordings and analysis}

Lognissimus muscle samples (300 g), taken in the region of the last thoracic vertebra, were obtained $24 \mathrm{~h}$ post-mortem, vacuum-packed and stored at $-20^{\circ} \mathrm{C}$ until 
required for $\alpha$-tocopherol and Se analysis, and lipid oxidation studies (less than 4 months). Fluorometric and high-performance liquid chromatographic (HPLC) determination were used separately to measure Se and $\alpha$-tocopherol contents (Daniels et al., 2000; O'Grady et al., 2001). Drip loss was measured following the procedures of Sun Yumin. Discoloration and lipid oxidation of the samples were analysed on $\mathrm{d} 1,3,5,10$ and 13 in $4^{\circ} \mathrm{C}$ storage. The colour of the muscle (CIE L*, $\mathrm{a}^{*}$, and $\mathrm{b}^{*}$ ) was measured using a Minolta chromameter. The level of lipid oxidation was determined using the thiobarbituric acid reactive substances (TBARS) method by a commercial kit (Nanjing Jiancheng Bioengineering Institute, China).

The data were analysed by ANOVA using the general linear model procedure of SAS (SAS Inst. Inc., Cary, NC). Differences between treatment means at the $5 \%$ level were determined using the least significant different test.

\section{RESULTS}

Dietary VE supplementation (500 or $1000 \mathrm{IU}$ per day) for $60 \mathrm{~d}$ led to an increase of $\alpha$-tocopherol concentration in serum and longissimus muscle of lambs $(\mathrm{P}<0.01)$, but no statistical difference between the two levels $(\mathrm{P}>0.05)$. Se supplementation at 0.2 or $0.4 \mathrm{mg} / \mathrm{kg} \mathrm{DM}$ also increased the Se concentration in serum and longissimus muscle $(\mathrm{P}<0.05$; Table 2$)$.

Table 2. The concentrations of $\alpha$-tocopherol and Se in serum and longissimus muscle of lambs

\begin{tabular}{|c|c|c|c|c|c|c|c|c|c|}
\hline \multirow{2}{*}{ Item } & \multicolumn{3}{|c|}{ VE } & \multicolumn{3}{|c|}{$\mathrm{Se}$} & \multirow{2}{*}{ SEM } & \multirow{2}{*}{$\mathrm{Se}^{*} \mathrm{VE}$} & \multirow{2}{*}{$\mathrm{P}$} \\
\hline & 0 & 500 & 1000 & 0 & 0.2 & 0.4 & & & \\
\hline \multicolumn{10}{|l|}{$\alpha$-tocopherol } \\
\hline $\mathrm{LM}, \mu \mathrm{g} / \mathrm{g}$ & $1.73^{\mathrm{B}}$ & $4.77^{\mathrm{A}}$ & $4.89^{\mathrm{A}}$ & 5.03 & 4.85 & 4.67 & 0.16 & NS & $<0.01$ \\
\hline serum, $\mu \mathrm{g} / \mathrm{ml}$ & $2.61^{\mathrm{B}}$ & $5.90^{\mathrm{A}}$ & $6.05^{\mathrm{A}}$ & 3.74 & 3.89 & 3.77 & 0.15 & NS & $<0.01$ \\
\hline \multicolumn{10}{|l|}{$\mathrm{Se}$} \\
\hline $\mathrm{LM}, \mu \mathrm{g} / \mathrm{kg}$ & 82.83 & 81.83 & 87.17 & $51.5^{\mathrm{B}}$ & $97.33^{\mathrm{A}}$ & $103.00^{\mathrm{A}}$ & 2.61 & NS & $<0.01$ \\
\hline serum, $\mu \mathrm{g} / 1$ & 114.67 & 115.67 & 114.50 & $84.00^{\mathrm{C}}$ & $104.33^{\mathrm{B}}$ & $156.50^{\mathrm{A}}$ & 3.05 & NS & $<0.01$ \\
\hline
\end{tabular}

LM - longissimus muscle; ${ }^{A, B, C}$ mean values in the same row with different superscripts are significantly different $(\mathrm{P}<0.01)$

As shown in Table 3, from $5 \mathrm{~d}$ of storage, drip loss of longissimus muscle decreased significantly with dietary VE supplementation at 500 and $1000 \mathrm{IU} / \mathrm{d}$ $(\mathrm{P}<0.05)$. The TBARS value increased in all treatments during storage for up to $13 \mathrm{~d}$. Dietary VE supplementation at $500 \mathrm{IU} / \mathrm{d}$ or $1000 \mathrm{IU} / \mathrm{d}$ was more effective in reducing lipid oxidation $(\mathrm{P}<0.01)$. Se supplementation had no significant effects on the lipid oxidation $(\mathrm{P}>0.05)$. The $\mathrm{a}^{*}$ values (redness) tended to decrease with the expanded storage. Dietary VE supplementation increased a* value of longissimus 
muscle after $10-13 \mathrm{~d}$ of storage at $4^{\circ} \mathrm{C}$. Increasing dietary organic Se level had no effects on the discoluration of muscle during the storage period $(\mathrm{P}>0.05)$.

Table 3. The effects of dietary VE and Se on drip loss, lipid oxidation and discoloration of longissimus muscle of lambs during storage at $4^{\circ} \mathrm{C}$

\begin{tabular}{|c|c|c|c|c|c|c|c|c|c|}
\hline \multirow{2}{*}{ Item } & \multicolumn{3}{|c|}{ VE } & \multicolumn{3}{|c|}{$\mathrm{Se}$} & \multirow{2}{*}{ SEM } & \multirow{2}{*}{$\mathrm{Se}^{*} \mathrm{VE}$} & \multirow{2}{*}{$P$} \\
\hline & 0 & 500 & 1000 & 0 & 0.2 & 0.4 & & & \\
\hline \multicolumn{10}{|c|}{ Drip loss, $\%$} \\
\hline 1 & 0.66 & 0.67 & 0.59 & 0.63 & 0.65 & 0.65 & 0.03 & NS & NS \\
\hline 3 & 1.76 & 1.60 & 1.39 & 1.50 & 1.71 & 1.55 & 0.17 & NS & NS \\
\hline 5 & 4.11 & $3.58^{\mathrm{b}}$ & $3.53^{\mathrm{b}}$ & 3.76 & 3.79 & 3.67 & 0.17 & NS & $<0.05$ \\
\hline 10 & $7.72^{\mathrm{A}}$ & $6.61^{\mathrm{B}}$ & $6.64^{\mathrm{B}}$ & 7.05 & 6.99 & 6.93 & 0.18 & NS & $<0.01$ \\
\hline 13 & $12.35^{\mathrm{A}}$ & $10.56^{\mathrm{B}}$ & $10.39^{\mathrm{B}}$ & 11.17 & 11.10 & 11.03 & 0.17 & NS & $<0.01$ \\
\hline \multicolumn{10}{|c|}{ TBARS values, nmol/mgProt } \\
\hline 1 & $0.25^{\mathrm{A}}$ & $0.15^{\text {В }}$ & $0.16^{\mathrm{B}}$ & 0.19 & 0.18 & 0.19 & 0.01 & NS & $<0.01$ \\
\hline 3 & $0.34^{\mathrm{A}}$ & $0.24^{\mathrm{B}}$ & $0.23^{\mathrm{B}}$ & 0.27 & 0.28 & 0.27 & 0.02 & NS & $<0.01$ \\
\hline 5 & $0.64^{\mathrm{A}}$ & $0.43^{\mathrm{B}}$ & $0.45^{\text {в }}$ & 0.51 & 0.51 & 0.5 & 0.02 & NS & $<0.01$ \\
\hline 10 & $1.05^{\mathrm{A}}$ & $0.66^{\mathrm{B}}$ & $0.65^{\mathrm{B}}$ & 0.78 & 0.78 & 0.78 & 0.02 & NS & $<0.01$ \\
\hline 13 & $1.24^{\mathrm{A}}$ & $0.84^{\mathrm{B}}$ & $0.85^{\mathrm{B}}$ & 0.97 & 0.99 & 0.97 & 0.02 & NS & $<0.01$ \\
\hline \multicolumn{10}{|l|}{$A^{*}$} \\
\hline 1 & 18.24 & 19.51 & 19.45 & 19.14 & 19.07 & 19.00 & 0.98 & NS & NS \\
\hline 3 & 17.74 & 18.76 & 18.44 & 18.41 & 18.43 & 18.12 & 1.34 & NS & NS \\
\hline 5 & 15.45 & 16.90 & 16.88 & 16.41 & 16.48 & 16.34 & 0.76 & NS & NS \\
\hline 10 & $12.97^{b}$ & $14.53^{\mathrm{a}}$ & $14.47^{\mathrm{a}}$ & 13.99 & 13.94 & 14.05 & 0.39 & NS & $<0.05$ \\
\hline 13 & $12.48^{\mathrm{b}}$ & $14.01^{\mathrm{a}}$ & $13.97^{\mathrm{a}}$ & 13.69 & 13.53 & 13.24 & 0.23 & NS & $<0.05$ \\
\hline
\end{tabular}

A, B, C mean values in the same row with different superscripts are significantly different $(\mathrm{P}<0.01)$ a,b,c mean values in the same row with different superscripts are significantly different $(\mathrm{P}<0.05)$

\section{DISCUSSION}

Dietary VE supplementation led to an increase in serum $\alpha$-tocopherol concentration after $60 \mathrm{~d}$ on the experiment diets. Increasing supplementation level from 500 to $1000 \mathrm{IU} / \mathrm{d}$ led to no further increase in serum $\alpha$-tocopherol concentration $(\mathrm{P}>0.05)$. The results indicate that a saturation level of serum $\alpha$-tocopherolwasreached with 500IU/dVEsupplementation.Elevatedbovineserum $\alpha$-tocopherol concentration and its saturation following dietary supplementation have been reported also in bovines (Arnold et al., 1993). In agreement with the findings of Ekholm et al. (1991), muscle $\alpha$-tocopherol concentrations were not significantly affected by dietary Se supplementation.

The effect of $\alpha$-tocopherol on lipid oxidation in animal tissues is well established (Morrissey et al., 1998; Guo et al., 2006). There was no significant effect of dietary 
Se on the oxidative stability of minced longissimus muscle, and no additional benefit. O'Grady (2001) reported that Se supplementation $(0.3 \mathrm{mg} / \mathrm{kg})$ in the beef cattle diets did not significantly affect glutathione peroxidase activity or susceptibility to lipid and oxymyoglobin oxidation in the presence or absence of vitamin E. The results were similar with given in this paper, but no similar reports were found in lambs. The oxidative stability of muscle lipid was improved by supplementation with 500 or $1000 \mathrm{IU}$ of $\alpha$-tocopheryl acetate/d after $10 \mathrm{~d}$ of storage $(\mathrm{P}<0.05)$, similar to the results reported (Arnold et al., 1992, 1993; Mitsumoto et al., 1993; Faustman et al., 1998, 1999). Avanzo et al. (2001) reported that $\alpha$-tocopherol affected peroxidation of the mitochondrial membranes by one order of magnitude higher than Se, which also suggested that $\alpha$-tocopherol, but not $\mathrm{Se}$, is the factor that markedly affects the course of lipid peroxidation.

The surface meat colour of lambs, as expressed by a*, were not affected by different dietary Se supplementations. Monahan et al. (1994) reported that until 8 $\mathrm{d}$ of storage, $\mathrm{a}^{*}$ values of chops from pigs fed $200 \mathrm{mg}$ of $\alpha$-tocopheryl acetate $/ \mathrm{kg}$ of feed are significantly higher than those of chops from pigs fed a basal diet (10 $\mathrm{mg} / \mathrm{kg}$ of feed), similar to the result of this study. In agreement with the results of Dufrasne et al. (2000), there were no significant difference of drip loss at $\mathrm{d} 1$ and 3 of storage $(\mathrm{P}>0.05)$. From d 5 of storage, the drip loss tended to decrease with dietary VE supplementation $(\mathrm{P}<0.05)$. No carcass measurement benefit resulted from dietary Se levels (Mahan et al., 1999).

\section{CONCLUSIONS}

Organic Se supplementation of lambs affected muscle Se content, but no significant influence on the oxidative stability. Dietary VE supplementation at 500 or $1000 \mathrm{IU} / \mathrm{d}$ led to elevated $\alpha$-tocopherol concentrations in serum and muscle and a decrease in the susceptibility of muscle tissue to lipid oxidation. The results suggest that adjusting dietary Se has limited potential, except perhaps when dietary Se is limiting, for increasing the oxidative stability of lamb or accentuating the stabilizing effect of VE.

\section{REFERENCES}

Arnold R.N., Arp S.C., Scheller K.K., Williams S.N., Schaefer D.M., 1993. Tissue equilibration and subcellular distribution of vitamin $\mathrm{E}$ relative to myoglobin and lipid oxidation in displayed beef. J. Anim. Sci. 71, 105-118

Arnold R.N., Scheller K.K., Arp S.C., Williams S.N., Buege D.R., Schaefer D.M., 1992. Effect of long- or short-term feeding of alpha-tocopheryl acetate to Holstein and crossbred beef steers on performance, carcass characteristics, and beef color stability. J. Anim. Sci. 70, 3055-3065 
Avanzo J.L., de Mendonca C.X., Pugine S.M., de Cerqueira Cesar M., 2001. Effect of vitamin E and selenium on resistance to oxidative stress in chicken superficial pectoralis muscle. Comp. Biochem. Physiol. C Toxicol. Pharmacol. 129, 163-173

Combs Jr. G.F., 1981. Influences of dietary vitamin E and selenium on the oxidant defence system of the chick. Poultry Sci. 60, 2098-2105

Daniels J.T., Hatfield P.G., Burgess D.E., Kott R.W., Bowman J.G., 2000. Evaluation of ewe and lamb immune response when ewes were supplemented with vitamin E. J. Anim. Sci. 78, 2731-2736

Dufrasne I., Marche C., Clinquart A., Hornick J.L., Van Eenaeme C., Istasse L., 2000. Effects of dietary vitamin $\mathrm{E}$ supplementation on performance and meat characteristics in fattening bulls from the Belgian Blue breed. Livest. Prod. Sci. 65, 197-201

Ekholm B.P., Varo P., Aspila P., Koivistoinen P., Syrjälä Qvist L., 1991. Transport of feed Se to different tissues in bulls. Brit. J. Nutr. 66, 49-55

Faustman C., Chan W.K., Schaefer D.M., Havens A., 1998. Beef color update: The role for vitamin E. J. Anim. Sci. 76, 1019-1026

Faustman C., Liebler D.C., Burr J.A., 1999. Alpha-tocopherol oxidation in beef and in bovine muscle microsomes. J. Agr. Food Chem. 47, 1396-1399

Gerloff B.J., 1992. Effect of selenium supplementation on dairy cattle. J. Anim. Sci. 70, 3934-3940

Goehring T.B., Palmer I.S., Olson O.E., Libal G.W., Wahlstrom R.C., 1984. Effects of seleniferous grains and inorganic selenium on tissue and blood composition and growth performance of rats and swine. J. Anim. Sci. 59, 725-732

Guidera J., Kerry J.P., Buckley D.J., Lynch P.B., Morrissey P.A., 1997. The effect of dietary vitamin E supplementation on the quality of fresh and frozen lamb meat. Meat Sci. 45, 33-43

Guo Q., Richert J.R., Burgess J.R., Orr D.M., Blair M., Grant A.L., Gerrard D.L., 2006. Effect of dietary vitamin E supplementation and feeding period on pork quality. J. Anim. Sci. 84, 3071-3078

Lauridsen C., Buckley D.J., Morrissey P.A., 1997. Influence of dietary fat and vitamin supplementation on $\alpha$-tocopherol levels and fatty acid profiles in chicken muscle membranal fractions and on susceptibility to lipid peroxidation. Meat Sci. 46, 9-22

Mahan D.C., Cline T.R., Richert B., 1999. Effects of dietary levels of selenium-enriched yeast and sodium selenite as selenium sources fed to growing-finishing pigs on performance, tissue selenium, serum glutathione peroxidase activity, carcass characteristics, and loin quality. J. Anim. Sci. 77, 2172-2179

Mitsumoto M., Arnold R.N., Schaefer D.M., Cassens R.G., 1993. Dietary versus postmortem supplementation of vitamin E on pigment and lipid stability in ground beef. J. Anim. Sci. 71, 18121816

Monahan F.J., Buckley D.J., Gray J.I., Morrissey P.A., Asghar A., Hanrahan T.J., Lynch P.B., 1990. Effect of dietary vitamin E on the stability of raw and cooked pork. Meat Sci. 27, 99-108

Monahan F.J., Gray J.I., Asghar A., Haug A., Strasburg G.M., Buckley D.J., Morrissey P.A., 1994. Influence of diet on lipid oxidation and membrane structure in porcine muscle microsomes. J. Agr. Food Chem. 42, 59-63

Morrissey P.A., Sheehy P.J.A., Galvin K., Kerry J.P., Buckley D.J., 1998. Lipid stability in meat and meat products. Meat Sci. 49, S73-S86

O'Grady M.N., Monahan F.J., Fallon R.J., Allen P., 2001. Effects of dietary supplementation with vitamin $\mathrm{E}$ and organic selenium on the oxidative stability of beef. J. Anim. Sci. 79, 2827-2834 